\title{
POPULATION Age StRUCTURE AND \\ The Budget DeFICIT
}

\author{
Derek H. C. Chen* \\ The World Bank \\ 1818 H Street, N.W. \\ Washington D.C. 20433 \\ U.S.A.
}

This paper focuses on the effects of age-structure changes on the size of budget deficits of national governments. More specifically, it determines whether differences in age structure can account for the observed differences in budget deficits across countries as well as across time. Via an extension of the untested theory of negative bequest motives advocated by Cukierman and Meltzer (1989), this paper argues that the commonly accepted notion that population aging tends to increase the budget deficits of economies is theoretically consistent. However, preliminary results from country and time fixed-effects panel regressions, estimated from 1975 to 1992 over 55 developed and developing countries, indicate statistical evidence for this postulation is present only in the developing countries but not in the developed countries.

\section{JEL Classification Numbers: E62, H30, J14}

\section{World Bank Policy Research Working Paper 3435, October 2004}

The Policy Research Working Paper Series disseminates the findings of work in progress to encourage the exchange of ideas about development issues. An objective of the series is to get the findings out quickly, even if the presentations are less than fully polished. The papers carry the names of the authors and should be cited accordingly. The findings, interpretations, and conclusions expressed in this paper are entirely those of the authors. They do not necessarily represent the view of the World Bank, its Executive Directors, or the countries they represent. Policy Research Working Papers are available online at http:/lecon.worldbank.org.

*The Knowledge for Development Program of the World Bank Institute. 


\section{Recognition of the Problem of Population Aging}

It has been a traditional notion that a country's demographic factors have little effect on the macroeconomy. However, in recent years, the effects of demography on the economy has been receiving much more attention. The new interest in population economics is largely in response to the overwhelming concern with population aging. Population aging, the demographic phenomenon which entails an increase in the percentage share of the elderly ${ }^{1}$ in the total population, was previously associated only with the developed countries. However, in recent years, trends of declining fertility rates, a dominant cause of population aging, have began to surface in the developing and less developed countries as well.

While it is true that population aging in these developing and less developed countries is still in the relatively early stages, the projected rates of increase of these elderly populations for the near future, on the other hand, is staggering. Up to 2025 , Asia and Latin America are expected to have the largest percentage increases in the share of the elderly population. This is most disconcerting as it implies that these developing countries will be achieving levels of population aging at much lower levels of per capita income than the industrial countries did, and would probably therefore not have sufficiently developed social security programs for universal coverage.

While the growth of the elderly share for many countries is projected to increase, the growth of the share of working age populations have been projected to decrease. These declines arise from the combined impact of low fertility rates on the working-age population entrants and the maturation of large cohorts into retirement. In addition, the labor force participation rates of men both above and below the normal retirement age have fallen sharply (OECD, 1988). The above effects would reduce the size of the labor force and as such, given present trends, there will not only be a larger elderly population to be supported but also a smaller working population to support it. This implies that the burden shouldered by each working person is likely to increase substantially in the near future. If this trend goes unchecked, population aging could very well lead to the collapse of many pay-as-you-go social security systems in the world the early part of this century.

Thus, population aging, being a global phenomenon, is causing deep concerns in both the developed and developing countries. As such, much research in demographic economics has been performed in the hope of finding a way to avert the impending oldage crises.

\footnotetext{
${ }^{1}$ An elderly person is defined as an individual who is at least of age 65.
} 
Given the above mentioned concerns, this paper investigates, by way of econometric techniques, the effects of the changes in age structure on the central government budget deficits of national governments. Following conventional wisdom, I argue in this paper that increases in the population share of the elderly will tend to increase the budget deficit and estimate fixed-effects panel regressions using data for 55 countries to verify the validity of this postulation.

\section{Population Age Structure Changes and the Budget Deficit}

\subsection{The Effects of the Elderly Share on the Budget Deficit}

The above changes in the age structure of the population bear significant impact on the level of public social expenditure and consequently, holding other things constant, the size of the budget deficit.

An unexpected rise in the population share of the elderly due to improved longevity tends to increase the budget deficit because this will increase the amount of social security benefits that are paid out to the elderly by the government. Such social programs are largely financed by taxes and social security contributions collected from the working population. Since the size of the elderly population relative to that of the working population also increases with the elderly share, holding other things constant, the benefits that are paid out will tend to exceed the revenue collected for such programs. This consequently means that the government, in order to keep such social programs viable, must increase the level of taxes and social security contributions being collected from the working population or decrease the level of social security benefits being paid out to the elderly, or run a budget deficit by financing some of the social security benefits by bond issuance ${ }^{2}$.

Population aging also tends to lead to an increase in the government deficit by increasing the government's expenditure on health care. Surveys conducted in OECD countries show that public expenditure on health care is significantly higher for older persons than for the remainder of the population. This is predominantly due to health problems and costly medical technologies being concentrated on the old. As such, an increase in the share of the aged generally leads to an increase in government expenditure on public health care services, which consequently, with a given level of tax revenue, tends to increase the budget deficit.

\footnotetext{
${ }^{2}$ Of course, there is also the obvious choice of using any combination of the three options.
} 
From a long-run perspective, an increase in the retired elderly share also tends to increase the budget deficit by decreasing the tax base of the economy. This hypothesis builds on the argument used in Bloom and Williamson (1997) ${ }^{3}$. An increase in the elderly share decreases the amount of per capita labor resource of the economy because an elderly person generally either works less than a person who is of workingage or does not work at all. With less per capita labor input, per capita income tends to be lower, leading to a lower level of income tax revenues, and consequently, the budget deficit increases.

In addition to working less, elderly persons also tend to dissave more than the average working-age individual. This implies that an economy with a larger elderly share, other things held constant, will tend to have a lower level of savings as compared to one with a smaller elderly share ${ }^{4}$. With a lower savings level, investment tends to be at a lower level which will lead to a lower level of per capita income and income tax revenues and consequently, a larger budget deficit.

In short, an economy with a larger elderly share of total population tends to have a larger budget deficit because of the tendency of increased social expenditures on health and social security and also because of lower per capita income due to lower level of labor and capital inputs into the economy.

\subsection{The Effects of the Youth Share on the Budget Deficit}

Similar to that of the elderly, an increase in the share of the youth in the total population tends to have an effect of increasing the budget deficit. With a larger share of the population as young persons, public expenditures by the government which are specifically directed at the youth, such as education expenditures, will increase.

Again similar to that of the elderly, a larger youth share will also imply that there are relatively less workers and savers in the economy. As such, the levels of per capita labor inputs and investment will be less, leading to a lower level of per capita income and income tax revenues and a larger budget deficit.

\footnotetext{
${ }^{3}$ Bloom and Williamson (1997) postulated and empirically demonstrated that an increase in the growth rate of the share of the dependent population, which includes both young and elderly persons, tends to decrease the rate of per capita income growth because the young and elderly work and save less.

${ }^{4}$ In an empirical study covering 80 over countries, Kelley (1988) finds that increases in the elderly share lead to statistically significant decreases in the aggregate saving rate.
} 


\subsection{Dependency Ratios and the Budget Deficit}

Rather than looking at the various age-group shares of the population, it is very common to study the variations in the youth and elderly dependency ratios as indicators of changes in the age structure of the population.

The elderly dependency ratio ${ }^{5}$ represents the size of the elderly population relative to that of the working-age population and has been projected to increase in all major regions of the world due to the effects of population aging. An increase in the elderly dependency ratio implies that the size of the elderly population has increased faster than that of the working population, and for reasons discussed above, should lead to an increase in the budget deficit.

Similarly, the young or youth dependency ratio is the number of young persons in the population divided by the number of persons in the working-age population. An increase in the youth dependency ratio implies that the size of the elderly population has increased faster than that of the working population, and should also lead to an increase in the budget deficit.

\subsection{Population Aging and the Budget Deficit : A Simple Model of Overlapping Generations}

To show mathematically in a simple way the effects of a larger share of the elderly population on the government budget deficit, we borrow from Diamond (1965) the standard overlapping generations model. It is thus assumed that each individual lives, without uncertainty, for two time periods. Every individual works when they are young, during the first period of their lives, and retires when they are old, in the second period of their lives. Wages are assumed to be perfectly flexible so that full employment prevails. Let $N_{t}$ be the number of persons in the young (working) population in period $t$ and $n_{t}$ be the growth rate of the young population in period $t$. This implies that:

$$
N_{t+1}=N_{t}\left(1+n_{t}\right)
$$

In any time period $t$, only two cohorts coexist, the young population of period $t$ and the elderly population of period $t$, which was the young population of time period $t-1$. The total population in time period $t, T P_{t}$, can be thus written as :

\footnotetext{
${ }^{5}$ The elderly dependency ratio is defined as the number of persons aged at least 65 to the number of persons aged between 15 and 64 multiplied by 100. It is interpreted as the number of aged persons being supported by 100 persons of working age.
} 


$$
\begin{aligned}
T P_{t} & = & N_{t}+N_{t-1} \\
& = & N_{t-1}\left(1+n_{t-1}\right)+N_{t-1} \\
& = & N_{t-1}\left(2+n_{t-1}\right)
\end{aligned}
$$

This consequently implies that the elderly share of the total population in time period $t$ can be expressed as :

$$
\begin{aligned}
\frac{N_{t-1}}{T P_{t}} & =\frac{N_{t-1}}{N_{t-1}\left(2+n_{t-1}\right)} \\
& =\frac{1}{2+n_{t-1}}
\end{aligned}
$$

Notice the negative relationship that exists between the share of the elderly population and the growth rate of the young population : the lower the growth rate of the young population, the larger the share of the elderly population.

Further assume the presence of a government which runs a pay-as-you-go social security system. The government taxes each young individual a fixed amount $T$ and pays out a fixed amount of social security benefits, $S S B$, to each old individual. The lump-sum taxes, $T$, that are levied on every young agent are set such that, given the amount of social security benefits, $S S B$, for every old agent in period 0 , the government will have a balanced budget. Thus by equating the total expenditures of the government with its total revenue, we get:

$$
\begin{array}{lll}
N_{-1} S S B & = & N_{0} T \\
& = & \left(1+n_{-1}\right) N_{-1} T \\
S S B & = & \left(1+n_{-1}\right) T
\end{array}
$$

Let $\bar{n}$ denote the young population growth rate that yields a balanced government budget in time period 0 and by definition it must equal to $n_{-1}$. We can therefore rewrite the previous equation as :

$$
S S B=(1+\bar{n}) T
$$

Let $D_{1}$ be the budget deficit in period 1. In this simple model it is mathematically expressed as the difference between the total government expenditure in period 1 and the total amount of taxes collected in period 1 : 


$$
\begin{aligned}
D_{1} & = & N_{0} S S B-N_{1} T \\
& = & N_{0}(1+\bar{n}) T-N_{0}\left(1+n_{0}\right) T \\
& = & N_{0} T\left(1+\bar{n}-1-n_{0}\right) \\
& = & N_{0} T\left(\bar{n}-n_{0}\right)
\end{aligned}
$$

It can be seen from above that given the lump-sum taxes, $T$, and social security benefits, $S S B$, that the growth rate of the young population determines the size of the budget deficit and if it falls below $\bar{n}$, a budget deficit would result. Thus in this simple model, the lower the growth rate of the young population the larger the budget deficit.

Recall that it has been shown that a lower growth rate of the young population also leads to a larger share of the elderly in the population. As such, there exists a positive association between the elderly share of the total population and the size of the budget deficit : a lower growth rate of the young population will lead to an increase in the elderly share which would consequently increase the level of the budget deficit.

\section{The Theory of Negative Bequest Motives}

In this section, we provide a brief description of another prominent theory of budget deficits that can be extended to explain the effects of age-structure changes on the budget deficit.

Cukierman and Meltzer (1989) focused on intergenerational redistributive effects of public debt, and proposed a political economy, general equilibrium model of debt and deficits based on intergenerational transfers. They argue that there exist bequestconstrained individuals who would like to transfer resources from future generations to finance current consumption, via negative bequests. As mentioned, since such negative bequests are typically not socially enforceable, bequest-constrained individuals will favor any fiscal policy that decreases current taxes without decreasing current government expenditures. Thus, in a democratic political system, the larger the share of bequestconstrained individuals in the population, the more likely is the government to run larger deficits. Based on this scenario, Cukierman and Meltzer theory of negative bequest motives postulate that increases in the expected rate of economic growth, the spread of 
the income distribution or expected longevity tends to increase the population share of bequest-constrained individuals, which will consequently lead to larger budget deficits.

\subsection{The Theoretical Framework}

Cukierman and Meltzer (1989), using an overlapping generations model with bequests, attempted to identify the factors that determine the size of budget deficits by focusing only on the redistributive role of the government. By doing so, they abstract from the function of the government as a provider of public goods and also from issues that relate to the minimization of the deadweight loss of taxation over time.

\section{Main Assumptions of the Model}

The economy is represented by an overlapping generations structure with bequests. The population is assumed to be stationary and the number of individuals in each generation, denoted by $N$, is identical across periods. Their model assumes there is no uncertainty, taxes are levied in a lump-sum fashion on the young, and the old receive Social Security benefits. Individuals work only when young and each supplies inelastically one unit of labor each period. There exists differences in ability and, consequently, in wage rates across individuals. The production function exhibits constant returns to scale technology.

Individuals are able to transfer wealth from the first to second period of life by means of savings either in the form of government bonds or capital investment. Familial intergenerational transfers, if any, are assumed to flow only from the parent to the child, that is, such transfers exist only in the form of bequests. The amount of bequests differs across individuals. As will be explained below, the position of each individual in the distribution of wealth, his wage rate and the wage rates he expects for future generations in his family determine his attitude toward the size of the budget deficit. Given individual preferences, majority rule determines the current period debt size and the current taxes chosen by voters.

Government expenditure is financed by a combination of lump-sum taxes on the young and issuance of one-period government bonds that have to be repaid with interest in the next period. The government budget constraint therefore implies that total current expenditure, consisting of social security payments plus the principal and interest payments on last period's government bonds, must be equal to total current revenue, 
consisting of the above mentioned lump sum taxes and new bond issue. The government budget constraint, normalized by the number of young or old individuals, $N$, can be thus written as:

$S_{t}+\left(1+r_{t-1}\right) b_{t-1}=T_{t}+b_{t}$

where

$S_{t} \quad$ is the social security payments paid out to the old in period $t$

$r_{t-1} \quad$ is the interest rate for period $t-1$

$b_{t-1} \quad$ is the amount of bonds issued in period $t-1^{6}$

$b_{t} \quad$ is the amount of bonds issued in period $t$

$T_{t} \quad$ is the amount of taxes levied in period $t$

Rearranging, we get the size of the budget deficit,

$b_{t}=S_{t}+\left(1+r_{t-1}\right) b_{t-1}-T_{t}$

which also denotes the stock of government debt in period $t$, since all bonds are oneperiod bonds.

\section{Bequest Motives and Preferences over the Budget Deficit}

Cukierman and Meltzer argue that Barro's (1974) government debt neutrality theorem does not hold when individuals differ in productivity, wage earnings, and also in their initial endowment. This is because these differences will give rise to some individuals who would like to leave a negative bequest to their descendants. However, such bequests cannot be discharged, as there are no institutional arrangements that can obligate their descendants to do so. The minimum bequest is thus constrained to zero and individuals who desire to leave negative bequests are termed as bequestconstrained individuals.

Clearly, such bequest-constrained individuals will favor a fiscal policy that increases their lifetime income at the expense of future generations even when the

\footnotetext{
${ }^{6}$ Note that all government bonds issued are one-period bonds. This implies that bonds issued in the preceding period must be retired and repaid in full with interest in the next period.
} 
present value of the tax change is zero. For example, increased social security benefits financed by debt issue shift taxes forward (that is, into the future) and allow bequestconstrained individuals to achieve a higher level of consumption. Thus, with such individuals, the issuance of government debt will not be neutral. All other things equal, under a majority rule political system, this implies a larger share of the population that is bequest-constrained will tend to lead to a larger budget deficit.

Cukierman and Meltzer further argue that, in their general equilibrium framework, even an individual who is not bequest-constrained, may still not be indifferent to a reallocation of resources over time that maintains present value. According to them, if there exist any bequest-constrained individuals in the economy, a present-valuepreserving exchange of taxes for public debt will increase the consumption of those individuals. These bequest-constrained individuals must obtain the required resources for additional consumption from the non-bequest-constrained, who substitute bonds for real capital in their portfolios. While bonds and capital are perfect substitutes in portfolios, they are not perfect substitutes in production. The additional debt crowds out some capital $^{7}$, raising the return to capital and decreasing the return to labor. Consequently, individuals will favor a debt increase if their income is largely capital income and will be against a debt increase if their income is mainly labor income ${ }^{8}$.

Based on the above model, Cukierman and Meltzer postulate that budgetary deficits will be larger under majority rule,

i. the larger the expected long-run growth rate of the economy

ii. the larger the spread of the income distribution

iii. the higher the longevity

i. All other things being equal, the higher the expected rate of future economic growth, the more the current generation will expect future generations to be relatively better off. This tends to increase not only the probability that the current generation will want to reallocate resources from the future to the present, but

\footnotetext{
${ }^{7}$ The amount of capital that is crowded out by an additional unit of debt depends on the fraction of bequest-constrained individuals in the economy and on the extent to which they are constrained.

${ }^{8}$ It is realized that for small open economies, the issue of addition government debt will not lead to an increase in interest rates and thus no crowding out of capital will occur. This point will be reiterated in a later section when the regression results are analyzed.
} 
also increases the amount of resources that is likely to be transferred. As such, economic growth tends to increase the number of individuals with negative bequest motives and also increases the degree to which individuals are bequest constrained, thus leading to a larger budget deficit under majority rule.

ii. Cukierman and Meltzer argue that individuals with extreme amounts of income and wealth tend to favor more debt issuance. Individuals with low incomes will tend to be bequest constrained, while individuals with high incomes tend to have capital income as their main source of income. Both of these groups of individuals will vote for more debt financing, but for different reasons ${ }^{9}$. Hence, the larger the spread of the distribution of income or total wealth, the larger the probability of having a larger budget deficit.

iii. Higher expected longevity tends to increase the expected length of time an individual spends in retirement ${ }^{10}$. This tends to increase the required amount of resources necessary to sustain consumption in the retirement years. Thus a higher expected longevity will tend to increase the proportion of the population who prefer negative bequests and also the size of the negative bequest that is preferred. This, in turn, tends to lead to a larger budget deficit, ceteris paribus.

\subsection{An Extension to the Theory of Negative Bequest Motives}

In view of Cukierman and Meltzer's postulation that an increase in expected longevity tends to increase the population share of bequest constrained individuals, it is obvious that it should not only be increases in expected longevity but also the number of persons who are actually in retirement that increases the population share of bequest constrained individuals. Thus, ceteris paribus, the larger the number of retired persons in the economy, the larger the number of persons who require additional resources for consumption during retirement, the larger the likelihood that the population share of bequest constrained individuals in the economy and consequently the larger the budget

\footnotetext{
${ }^{9}$ Recall that the return to capital tends to increase in debt issuance in the Cukierman-Meltzer model.
} 
deficit. This implies that an increase in the elderly population share should have a positive effect on the size of the budget deficit.

Using similar arguments, it should also be true that an increase in the workingage population share should decrease the decrease the population share of bequest constrained individuals thereby leading to smaller budget deficits. Thus, an increase in the working-age share should lead to a decrease in the budget deficit. ${ }^{11}$

\section{Other Variables and the Budget Deficit}

Before an empirical investigation into the issue of whether changes in agestructure are significant driving forces behind the size of a country's budget deficit can be carried out, other structural and political variables that influence the size of the deficit must be first accounted for. There are 4 other main classes of variables that have been suggested in the literature to have significant effects on the size of the budget deficit of a country. They are

1. structural variables that determine or reflect the level of efficiency of the tax system in a country,

2. macroeconomic variables,

3. political variables representing the level of political instability and political polarization in a country, and

4. tax-smoothing variables.

\subsection{The Efficiency of the Tax System}

The efficiency of the tax system has been emphasized by Edwards and Tabellini (1991) and Cukierman et al. (1992) as an important determinant of the size of the budget deficit. They noted that an economy with an inefficient tax system, holding other factors constant, cannot collect as large an amount of tax revenues as an economy with an efficient tax system. This is primarily because an inefficient tax system has higher costs

\footnotetext{
${ }^{10}$ Thus the case in which higher longevity increases the length of an individual's working life is not considered.

${ }^{11}$ We are aware that our Bloom and Williamson type postulation that increases in the youth population share tends to increase the budget deficit is not explained by the theory of negative bequest motives.
} 
of tax collection and administration, not to mention more widespread tax evasion. Because of this lower level of tax revenues, economies with inefficient tax systems tend to have larger (and more monetized) budget deficits as compared to economies with efficient tax systems for any given level of government expenditure.

Because the taxing capacity of a country is technologically constrained by the structure of its economy and its stage of economic development, factors influencing the level of efficiency of the tax system in a country can be grouped into two categories ${ }^{12}$ : variables that account for the sectoral composition of GDP, and the stage of economic development.

The agricultural sector might be the hardest sector of the economy to tax. Its typically non-corporate structure facilitates tax evasion. Therefore, the larger the relative size of the agricultural sector in an economy, the higher the costs of administration and enforcement of tax collections will be. This implies a less efficient tax system, thus leading to a larger budget deficit for a given level of government expenditures.

On the other hand, the manufacturing sector is generally regarded as one of the easiest to tax. This is because, in sharp contrast to the agricultural sector, the manufacturing industry is largely corporate in structure, making it less capable of tax evasion. Thus, when an economy has a relatively large manufacturing sector, it should face lower tax enforcement costs implying a more efficient tax system, and consequently it should have a smaller budget deficit.

A third sectoral share, imports plus exports as a fraction of GDP, measures the foreign trade sector of the economy. Import and export taxes are commonly regarded as a cheap tax base because they are relatively easy to assess and collect since such foreign traded commodities must pass through a limited number of frontier ports, and are usually handled by a few wholesalers. The ease of collecting such taxes is one reason why countries with extensive foreign trade typically collect a greater proportion of public revenues in the form of import and export duties than countries with limited external trade (Todaro, 1997). An economy with a larger foreign sector, ceteris paribus, should therefore be able to collect more tax revenue thus leading to a smaller budget deficit.

Finally, since tax collection costs are likely to be smaller in urban areas than in rural areas. As such, the higher the urban population share out of the total population should be negatively associated with the budget deficit.

\footnotetext{
${ }^{12}$ See Cukierman et al. (1992) and Edwards and Tabellini (1991).
} 


\subsection{Macroeconomic Variables}

\section{a. Level of Economic Development}

To control for the potential effects of economic development on the cross-country differences in budget deficits, several different measures of the level of per capita real GDP will be used. Possible measures include real GDP per capita and a measure of potential or trend real GDP per capita. Detailed description of the construction of these variables will be given in the appendix.

\section{b. Accounting for Money Creation}

The budget deficit can be defined as the sum of the different ways in which it can be financed. Typically, budget deficits can be financed either by borrowing from the public or by seigniorage ${ }^{13}$, which implies that the budget deficit can be written as:

\section{Budget Deficit $\quad=\quad$ Non-monetized Debt Issue + Change in Base Money}

The bequest motive theory of budget deficits hinges wholly on the assumption that the deficit is financed by public debt issuance. Therefore, if a country runs a large budget deficit and finances it by monetizing it, the bequest motive theory provides no explanation as to why the budget deficit should arise. This is because monetization of

\footnotetext{
${ }^{13}$ Note that there are countries for which the budget deficit is not equal to the sum of the debt issued or retired and the amount of money created. For example, Singapore has been generally running budget surpluses since the 1980s; however, its stock of government debt has been increasing. This implies that the Singapore government has chosen not to pay off debts that it owes to the public, even though it has the surpluses to do so. In fact, it has chosen to borrow even more, in spite of accumulating large government reserves due to the many years of budget surpluses. This interesting case of Singapore, which provides a contradiction to the above "identity", illustrates that it is not always the case that when a country runs a budget surplus, the stock of national debt should, ceteris paribus, decrease and vice versa, which is clearly assumed by Cukierman and Meltzer here and by many others in the literature. The above equation perhaps should be rewritten as:

\section{Assets}

Budget Deficit $=$ Non-monetized Debt Issue + Money Creation - Change in Government

We did not control for changes in government assets due to a lack of available data and because changes in government assets is in many ways similar to debt issue, within the framework of the negative bequest motive model. Bequest constrained individuals should be indifferent between budget deficits that are financed by public debt issue or by sale of government assets, since in both cases current consumption increases at the expense of future generations.
} 
the deficit is equivalent to the imposition of an inflation tax, and this leads to a decrease in the real disposable income that should result in an increase the degree to which people are bequest-constrained. Thus, bequest-constrained individuals would not favor an increase in the budget deficit that is financed by money creation.

As such, when testing the bequest motive theory of budget deficits, it is necessary to control for the seigniorage-financed portion of the deficit, leaving the component of budget deficit that has been financed by debt issuance to be explained by bequest-constrained motives ${ }^{14}$. Following Roubini (1991), we use the change in the monetary base (as a share of GDP) to control for seigniorage revenue.

\section{c. Accounting for Interest Payments on Government Debt}

Interest rates are an important factor in determining governments' costs of debt servicing. Naturally, the costs of debt servicing become more important in countries that have a large stock of government debt, such as Belgium, Ireland and Italy. We will use the measure of the budgetary costs of higher interest rates presented in Roubini and Sachs (1989b), which is the annual change of the difference between the real interest rate and the real growth rate, multiplied by lagged debt-GDP ratio.

\subsection{Political Instability}

Political instability has been found to play a significant role in the determination of the size of the budget deficits ${ }^{15}$.

\footnotetext{
${ }^{14}$ Roubini and Sachs (1989a) showed that there is some evidence that policymakers treat seigniorage and bond issues as alternative ways to finance a budget deficit. Thus if some countries are constrained in their use of seigniorage taxation, they would switch to debt issuance to finance a given level of level of budget deficit. It is clear that in such a case, even if the budget deficit is financed by public debt issue, the Cukierman-Meltzer model does not provide an explanation for such a component of the budget deficit. Roubini and Sachs (1989a) also argue that due to their commitment to peg to the Deutsche Mark, member countries of the European Monetary System (EMS) experienced a reduction in seigniorage collections as they induced a slowdown in inflation and they found evidence that the decrease in seigniorage financing was accompanied by a more rapid increase in public debt.

${ }^{15}$ See Cukierman et al. (1992), Edwards and Tabellini (1991), and Roubini (1991). These papers actually argue that both political instability and political polarization are significant determinants of
} 
Edwards and Tabellini (1991) postulate that the more politically unstable a country is, the larger will be its budget deficit. Political instability will raise the frequency of government changes and lower the likelihood that a current policymaker will be reelected. Given this, consider a policymaker who is required to choose both the intertemporal profile of spending and taxes as well as how to allocate the resources acquired by issuing debt. Suppose that because of political instability in the country, the policymaker is aware that in the future he may be replaced by a policymaker or political majority with different preferences about some aspects of fiscal policy. Then he realizes that, whereas he is in control of how to allocate the proceeds of his borrowing, the allocation of the burden of repaying the debt in the future may not be under his control. This asymmetry may prevent the current policymaker from fully internalizing the costs of running a deficit, the more so the greater is the difference between his preferences and the expected preferences of the future majority. In simple terms, the policymaker may wish to borrow in excess of the optimum and let his successors "pay the bills". Thus, political instability and polarization tends to lead to a larger than optimal size of the budget deficit, even if the policymaker and the voters are rational and forward-looking.

This paper will use the frequency of government crises to proxy for political instability ${ }^{16}$. The number of government crises is defined as the number of major government crises, defined as any rapidly developing situation that threatens to bring the downfall of the present regime - excluding situations of revolt aimed at such overthrow.

\subsection{Political Freedom}

\footnotetext{
the size of budget deficits. However, it is noted that a country that is politically polarized may not be politically unstable. For example, a country can have two very different or polarized political ideologies and yet be politically stable if the supporters of one of the political ideology form the vast majority of the voter population, assuming majority rule. For this reason we have decided to omit the concept of political polarization in our presentation of political instability as a significant determinant of budget deficits.

${ }^{16}$ It was originally intended to follow Edwards and Tabellini (1991) and Roubini (1991) in using the frequency of government changes (both regular and irregular) as a measure of political instability. However, the data series for the frequency of government changes or total executive transfers obtained from Taylor (1985) is short, ending in 1983. As such, the number of government crises is used as a substitute. This alternative measure is crude since a government crisis does not necessarily lead to a change in the government. In addition, this measure excludes situations of revolt to overthrow the government, which should be included in a measure of political instability.
} 
Recall that Cukierman and Meltzer rely on the majority rule or a democratic political system for their theory of budget deficits. Thus, it is important to control for time periods during which citizens of a country may not have the political freedom to vote, such as when a country is under a military dictatorship.

\subsection{Tax-Smoothing Variables}

Neoclassical theory of fiscal policy is represented by the tax smoothing or equilibrium approach to fiscal deficits. According to this approach, advocated by Barro (1979), actual tax and deficits policies are a reflection of an intertemporal optimization over a long time horizon by the fiscal authorities, which choose their policies to reduce the excess burden of taxation. It is shown that the excess burden of taxation is minimized when the tax rate is constant in every period.

As a consequence, budget deficits and surpluses are postulated by the theory to act as buffers to unanticipated and transitory changes in government expenditures or output. When budget deficits are run, the tax-smoothing approach would argue that the economy is probably facing unexpected increases in government expenditures or unexpected decreases in output. On the other hand, if governments were running budget surpluses then tax-smoothing advocates would argue that the economy is experiencing unexpected decreases in government expenditures or unexpected increases in output.

This implies that increases in unanticipated changes in government expenditures should lead to increases in the budget deficit. On the other hand, increases in unanticipated output should lead to decreases in the budget deficit. Detailed description of these tax-smoothing variables are given in the appendix.

\section{Econometric Methodology}

In this paper, we investigate the validity of our theory of the effects of population age-structure and the budget deficit by using fixed-effects panel regressions. The use of panel regressions enables us to simultaneously account for intertemporal and cross differences in the budget deficits by having both short run (tax-smoothing) and long-run 
(bequest motives and age structure) independent variables in the regression specification. In addition, the incorporation of all these variables into a single specification allows a simultaneous test to the validity of all of these theories.

These panel regressions were estimated for the period 1975 to 1992 and both country and time fixed effects were used. Annual observations were used and countries did not have the same number of observations ${ }^{17}$. Estimating panel regressions calls for particular care in accounting for the dynamic properties of the variables. In addition to the control variables mentioned above, we also include a lagged dependent variable to reduce the serial correlation of the error terms.

\section{Missing Data Technique}

A major problem with estimating cross-country regressions that use socioeconomic variables is that there will be many missing observations. In our case, data on the Gini coefficient and life expectancy at age 65 are often sparse and available at irregular intervals. The problem is exacerbated by the fact that it is usually the less developed countries with the missing data for these variables, and it is the less developed countries that are likely to exhibit bequest constrained behavior. Thus, the exclusion of countries due to the lack of socio-economic (or any) data is likely to introduce a systematic bias against the existence of negative bequest motives.

In an attempt to harvest all the information we can from our data set, we use a method developed by Griliches (1986) for the treatment of missing data or observations. From the data appendix, it will be seen that we have been able to work around the problem of having insufficient observations for elderly life expectancy by obtaining predicted values of elderly life expectancy by using data on life expectancy at birth, which is highly correlated to elderly life expectancy. Since we do not have a variable that is highly correlated with the Gini coefficient, we will apply this missing data technique to the Gini coefficient.

The technique involves three stages. In the first stage, we perform the "normal" estimation of the fixed effects panel regression with the dependent variable budget surplus share being regressed on all independent variables, including the Gini coefficient:

\footnotetext{
${ }^{17}$ In the jargon of panel data analysis, the panel is "unbalanced".
} 


\section{Stage 1 Regression}

$$
Y_{i t}=\beta_{0}+\alpha_{C i}+\alpha_{Y t}+\beta_{1} Y_{i, t-1}+\sum_{n=2}^{N} \beta_{n} X_{n i t}+\varepsilon_{i t} \quad \forall i, t
$$

where

$i \quad$ is the country index

$t \quad$ is the year or time index

$\alpha_{C i} \quad$ is the country specific effect for country $i$

$\alpha_{Y t} \quad$ is the time specific effect for year $t$

$Y_{i, t-1} \quad$ is the budget surplus share lagged by one year

$X_{n} \quad$ is the $n^{\text {th }}$ explanatory variable.

In the second stage, we regress the Gini coefficient on all of the other independent variables used in the Stage 1 panel regression and obtain the predicted values of the Gini coefficient from this regression:

\section{$\underline{\text { Stage } 2}$ Regression $^{18}$}

$$
(\text { Gini })_{i t}=\gamma_{0}+\mu_{C i}+\mu_{Y t}+\gamma_{1} Y_{i, t-1}+\sum_{n=2}^{N-1} \gamma_{n} X_{n i t}+\varepsilon_{i t} \quad \forall i, t
$$

where

$\mu_{C i} \quad$ is the country specific effect for country $i$

$\mu_{Y t} \quad$ is the time specific effect for year $t$

Using the predicted values of the Gini coefficient from the Stage 2 regression, we generate a new variable, say "new Gini". This new Gini will take the original value of the Gini if it is present, and will take on the predicted value if the actual Gini value is missing ${ }^{19}$. This new Gini together with the estimated coefficient of the Gini variable from the Stage 1 regression is used to construct a new measure of the dependent variable:

\footnotetext{
${ }^{18}$ Note that the number of explanatory variables only goes up to $\mathrm{N}-1$ because the Gini coefficient is excluded.

${ }^{19}$ Note that the Stage 1 regression will generate a predicted value of the Gini coefficient for a certain country and year so long as none of the other independent variables is missing for that country and year.
} 
$(\text { New Surplus Share })_{i t}=(\text { Surplus Share })_{i t}-\beta_{\text {Gini }}(\text { new Gini })_{i t}$

Stage 3 of the missing data technique involves the estimation of the regression with the new measure of the surplus share as the dependent variable, being regressed on all of the independent variables, with the exception of the Gini coefficient:

\section{Stage 3 Regression}

$$
(\text { new } Y)_{i t}=\beta_{0}+\alpha_{C i}+\alpha_{Y t}+\beta_{1} Y_{i, t-1}+\sum_{n=2}^{N-1} \beta_{n} X_{n i t}+\varepsilon_{i t} \quad \forall i, t
$$

The estimated coefficients will be thus obtained from the Stage 3 Regression, with the exception of the Gini variable, which will be obtained from the Stage 1 Regression. While this missing data technique does not increase the efficiency of the estimated coefficient of the Gini variable, it does allow the rest of the coefficients to be estimated more efficiently by increasing the number of observations being used in the estimation ${ }^{20}$.

${ }^{20}$ In order for the coefficients of the non-missing independent variables to be estimated more efficiently, the probability of the Gini coefficient being missing must not be correlated with the level of the budget surplus share. We perform a simple rank test where the mean of the budget surplus shares for each of the 87 countries over the years 1975 to 1992 is ranked. By casual inspection, we see no correlation between the countries with no Gini data and the level of the budget surplus share. 


\section{Empirical Results}

From Table 1 we see that both increases in the population shares of the young and the elderly tend to decrease the budget surplus shares only in the developing countries, with both variables having estimated negative but insignificant coefficients (Reg 1b). For the developed countries, we see that increases in the population shares of the youth and aged tend to increase the budget surplus share of GDP with the estimated coefficient for the elderly population share being significant (Reg 1a). We therefore see that the data from developing countries tend to support the age structure of budget deficits, while those from developed countries do not.

We alternatively proxy age-structure changes in the population using the population shares of the working-age and the elderly and present the results as Reg $2 a$ and $2 b$ in Table 1 . We see that increases in the working-age population leads to an increase in the budget surplus share and increases in the aged share continues to lead to a smaller budget surplus share in developing countries (Reg 2b). Developed countries continue to exhibit estimated coefficients that are theoretically inconsistent with the working-age share having a negative coefficient and the elderly share having a positive coefficient. Note that the coefficients of all population share variables, for both developed and developing countries, are statistically insignificant. Thus, in view of our regression results, the evidence supporting conventional wisdom that population aging tends to lead to budget deficits is weak and only found in the developing countries.

Due to the relationship between life expectancy and the population share of elderly persons in an economy, we note that the correlation between the two variables is high, especially among the developing countries ${ }^{21}$. In this light, we reestimate the regressions with the life expectancy at age 65 variable dropped and present the results in Table 2. We see that the developing countries maintain the negative coefficients for the youth and elderly population shares, with that for the youth population turning statistically significant at the 90 percent confidence level (Reg 3b). The absence of the life expectancy variable as an explanatory variable also does not affect the coefficients of the youth and elderly share variables for the developed countries; both coefficients are still positive with that of the elderly share remaining statistically significant (Reg 3a).

Similar results are obtained using the working-age and elderly population shares when the regressions are estimated without the life expectancy at age 65 variable.

${ }^{21}$ The correlation coefficient between life expectancy at age 65 and the elderly population share is 0.22 for the developed countries and 0.71 for the developing countries. 
Dropping the life expectancy variable has little bearing on the estimated coefficients of the population share variables. The developing countries have a significant positive estimated coefficient of the working-age share and a negative coefficient for the elderly share (Reg 4b). The developed countries, on the other hand, have the reverse, with the working-age share exhibiting a negative coefficient and the elderly share exhibiting a positive one (Reg $4 a)$.

As opposed to capturing the effects of age structure changes by using agestructure shares, changes in age-structure of the population are instead measured by changes in the total dependency ratio in Reg $5 a$ and $5 b$ shown in Table 3 . As mentioned earlier, increases in the size of the youth or elderly population relative to that of the working-age population lead to increases in the total dependency ratio. As such, an increase in the total dependency ratio has a postulated negative effect on the budget surplus. We see that the regression results are basically in accord those from Table 1. Increases in the total dependency ratio tend to have a negative effect on the budget surplus only in the developing countries (Reg $5 \mathrm{~b}$ ) but not in the developed countries (Reg 5a).

Recall that the total dependency ratio can be decomposed into the youth and the elderly dependency ratios. We proceed to use the two dependency to measure agestructure changes in the population. It should be clear that increases in either of the dependency ratios are postulated to have a negative effect on the budget surplus share. In Table 3, we see that increases in either of the dependency ratios do indeed lead to a fall in the budget surplus share even though the effects are statistically insignificant, but only for the developing countries (Reg 6b). For the developed countries, increases in the youth dependency ratio tend to decrease the budget surplus share, as theoretically postulated. However, increases in the elderly dependency ratio tends to increase the budget surplus share, which is theoretically unexpected.

To summarize, regardless of the various demographic indices used to proxy agestructure changes used in our panel regressions, we see that empirical evidence supporting the age-structure theory of the budget deficit is found in developing countries, even though the evidence is rather weak given that the effects are not statistically significant. Developed countries, on the other hand, give no indication whatsoever that increases in the elderly share of the population increases the budget deficit. In fact, we consistent find evidence supporting the converse; increases in the elderly population in the developed country tends to decrease the budget deficit of central governments. 
Given that our population age-structure theory of the budget deficit can be viewed as an extension of the Cukierman Meltzer theory of negative bequest motives, we find it worthwhile to point out evidence suggesting bequest motives effects can be observed in developing countries. All three of the estimated coefficients of the bequest motive variables are consistently of the postulated negative sign, with that of the life expectancy variable being significant at least at the 90 percent confidence level.

On the other hand evidence supporting bequest motive effects are much weaker in the developed countries. In all of the regressions mentioned above, only two out of three of the bequest motive variables have the theoretically postulated negative sign with the Gini variable consistently exhibiting a positive coefficient ${ }^{22}$. In our opinion, we think that it is much more than a coincidence that developing countries tend to exhibit relatively stronger evidence for the negative bequest motives and population agestructure theories of the budget deficit. We therefore argue that the above suggest that negative bequest motives do exist in developing countries and consequently agestructure changes, such as population aging, do affect the budget deficit because it affects the population share of bequest constrained individuals.

We also see from Table 1 that the tax-smoothing theory tends to hold for the developing countries but not for the developed countries. The estimated coefficients for the unanticipated changes in per capita real government expenditure variables are negative and significant for both developed and developing countries, although it is highly significant only in the developing countries case. On the other hand, we see that the estimated coefficient for the unanticipated changes in per capita real output is positive and significant for the developing countries and of the negative (incorrect) sign for the developed countries.

\footnotetext{
${ }^{22}$ We note that the estimated coefficient for the expected GDP growth rate for the developed countries is consistently of the theoretically postulated negative sign and statistically significant at least at the 90 confidence level.
} 


\section{Conclusion}

In view of the wide-spread concern with regard to population aging leading to the government expenditures of many countries to be unsustainable in the near future, this paper attempts to assess the severity with which changes in population age structure affect the budget deficit of national central governments. By using fixed-effects panel regressions over 87 countries, I find that there is some evidence that increases in the elderly and youth population shares tend to increase the budget deficit, but only in developing countries. In addition, there is some indication that these age-structure effects on the budget deficit occur as a consequence of negative bequest motives. 


\section{References :}

Aizenman, Joshua (1987). "Inflation, Tariffs and Tax Enforcement Costs." Journal of International Economic Integration. Vol. 2, No. 2, pp 12-28.

Alesina, Alberto and Roberto Perotti (1995). "The Politcal Economy of Budget Deficits." IMF Staff Papers. Vol. 42, No. 1, March

Anderson, Gary M. (1986). "The US Federal Deficit and National Debt: A Political and Economic History." In Deficits, edited by James M. Buchanan, Charles K Rowley and Robert D. Tollison, Basil Blackwell Inc, pp. $9-46$.

Barro, Robert J. (1974). "Are Government Bonds Net Wealth ?" Journal of Political Economy. Vol. 82, No. 6, pp 1095-1117.

Barro, Robert J. (1979). "On the Determination of the Public Debt." Journal of Political Economy. Vol. 87, No. 5, pp 940-971.

Barro (1991) : "Comments on McCubbins" in Politics and Economics in the Eighties. ed by Alberto Alesina and Geoffrey Carliner. University of Chicago Press and National Bureau of Economic Research.

Berg, Andrew and Jeffrey Sachs (1988). "The Debt Crisis : Structural Explanations of Country Performance." Journal of Development Economics. Vol. 29, No. 3, pp 271-306.

Bloom, David E. and Jeffrey G. Williamson (1997). Demographic Transitions and Economic Miracles in Emerging Asia. Working Paper, Harvard Institute for International Development, Harvard University.

Buchanan, James M. and Richard E. Wager (1977). Democracy in Deficit : The Political Legacy of Lord Keynes. Academic Press, New York.

Buchanan, James M. and Jennifer Roback (1987). The Incidence and Effects of Public Debt in the Absence of Fiscal Illusion." Public Finance Quarterly. Vol. 15, pp. 5-25.

Clingermayer, James C. (1991). "An Intergenerational Transfer Model of State Debt Financing." Public Choice. Vol. 72, No. 1, pp. 13-21.

Cukierman, Alex, Sebastian Edwards and Guido Tabellini (1992). "Seigniorage and Political Instability." American Economic Review. June, Vol. 82, No. 3, pp 537-555.

Cukierman, Alex and Allan H. Meltzer (1989). "A Political Theory of Government Debt and Deficits in a Neo-Ricardian Framework." American Economic Review. September 1989, Vol. 79, No. 4, pp 713-732.

Culter, David M., James M. Poterba, Louise M. Sheiner and Lawrence H. Summers (1990). "An Aging Society : Opportunity or Challenge ?" Brookings Papers on Economic Activity. No. 1, pp. 1-73.

Diamond, Peter A. (1965). "National Debt in a Neoclassical Growth Model." American Economic Review. December, Vol. 55, pp. 1126-1150.

Edwards, Sebastian and Guido Tabellini (1991). "Explaining Fiscal Policies and Inflation in Developing Countries." Journal of International Money and Finance. Vol. 10 (Supplement), pp. S16-S48. 
Eisner, Robert (1989). "Budget Deficits: Rhetoric and Reality." Journal of Economic Perspectives. Vol. 3, No. 2, Spring, pp. 73-93.

Elmendorf, Douglas W. and N. Gregory Mankiw (1998). "Government Debt." NBER Working Paper No. 6470, March.

Griliches, Zvi (1986). "Economic Data Issues." in Handbook of Econometrics. (Volume 3) ed by Zvi Griliches and Michael D. Intriligator. North-Holland, Netherlands.

Hoover, Kevin D. and Mark Siegler (2000). "Taxing and Spending in the Long View: The Causal Structure of U.S. Fiscal Policy, 1791-1913." Oxford Economic Papers. (forthcoming)

Johnson, D. Gale (1998). "Population and Economic Development." Seminar Paper presented at University of California at Davis, November 13, 1998.

Kelly, Allen C. (1988). "Population Pressures, Saving, and Investment in the Third World : Some Puzzles." Economic Development and Cultural Change. Vol. 36, No. 3, pp 449-464.

Kristov, Lorenzo, Peter Lindert and Robert McClelland (1992). "Pressure Groups and Redistribution." Journal of Public Economics. Vol. 48, pp. 135-163.

Lindert, Peter H. (1996). "What Limits Social Spending?" Explorations in Economic History. Vol. 33, pp. 1-34.

Mankiw, G. (1987) "The Optimal Collection of Seigniorge: Theory and Evidence." Journal of Monetary Economics. Vol. 20, pp. 327-342.

Meltzer, Allan H. (1992). "Measurement, Economic, and Political Issues of Debt and Deficits." In Marvin H. Kosters (ed), Fiscal Politics and the Budget Enforcement Act. The American Enterprise Institute (AEI) Press.

Meltzer, Allan H. and Scott F. Richard (1981). "A Rational Theory of the Size of Government." Journal of Political Economy. Vol. 89, pp 914-927.

Meltzer, Allan H. and Scott F. Richard (1981). "Tests of a Rational Theory of the Size of Government." In Allan H. Meltzer, Alex Cukierman and Scott F. Richard. Political Economy. Oxford University Press.

Ross, Levine and David Renelt (1992). "A sensitivity Analysis of Cross-Country Growth Regressions." American Economic Review. September, Vol. 82, No. 4, pp. 942-963.

Roubini, Nouriel and Jeffrey Sachs (1989a). "Government Spending and Budget Deficit in the Industrial Countries.” Economic Policy. April, Vol 8 pp 100-132.

Roubini, Nouriel and Jeffrey Sachs (1989b). "Political and Economic Determinants of Budget Deficits in the Industrial Democracies." European Economic Review. Vol. 33, pp 903-938.

Roubini, Nouriel (1991). "Economic and Political Determinants of Budget Deficits in Developing Countries." Journal of International Money and Finance. Vol. 10 (Supplement), pp S49-S72.

Tait, Alan A., Wilfrid L.M.Gratz and Barry J. Eichengreen (1979). "International Comparisons of Taxation for Selected Developing Countries, 1972-76." IMF Staff Papers. Vol. 26, pp 123-156, March. 
Sahasakul, C. (1986). "The U.S. Evidence on Optimal Taxation over Time." Journal of Monetary Economics. Vol. 18, pp. 251-275.

Schick, Allen (1983). "The Distributive Congress." in Schick, Allen (ed.) Making Economic Policy in Congress. Washington D.C. American Enterprise Institute, pp. 257-74.

Vaughn, Karen I. and Richard E. Wagner (1992). Public Debt Controversies : An Essay in Reconciliation." Kyklos. Vol. 45, Fasc. 1, pp 37-49.

\section{BOOKS}

Chen, Derek Hung Chiat (1995). Ageing and Intergenerational Transfers : The Issues. (Unpublished) Master's dissertation. National University of Singapore, Republic of Singapore. Chen, Derek Hung Chiat (2001). Intertemporal Excess Burdens, Bequest Motives, Informal Support and the Budget Deficit. (Unpublished) Doctoral dissertation. Univeristy of California at Davis.

OECD (1988). Ageing Populations : The Social Policy Implications. OECD, Paris, 1988.

O'Sullivan, Arther and Steven M. Sheffrin (1998). Macroeconomics : Principles and Tools.

Prentice-Hall, Inc., New Jersey.

Rosen, Harvey S. (1999). Public Finance. ( $5^{\text {th }}$ Edition) Irwin / McGraw-Hill, U.S.A.

Taylor, John B. (1998). Principles of Macroeconomics. (2nd Edition) Houghton Mifflin Company, U.S.A.

Todaro, Michael P. (1997) Economic Development. (6th Edition) Addison-Wesley Publishing Company, Inc., U.S.A.

\section{DATA SOURCES}

Deininger, Klaus and Lyn Squire (1996). A New Data Set Measuring Income Inequality. World Bank Economic Review. Vol. 10, pp. 565-591.

Easterly, William (1997). "Life During Growth.” Journal of Economic Growth. Vol. 4, Issue 3, September 1999.

Gastil, R.D. (1973-1989). "The Comparative Survey of Freedom." Freedom at Issue. Various Issues.

Heston, Alan and Robert Summers (1991). "The Penn World Table (Mark 5) : An Expanded Set of International Comparisons, 1950-1988." Quarterly Journal Economics. May, pp. 327-368.

International Monetary Fund. International Financial Statistics. Various Issues.

International Monetary Fund (1998). International Financial Statistics. CD-Rom

International Monetary Fund (1999). International Financial Statistics. CD-Rom

Taylor, Charles Lewis (1985). World Handbook of Political and Social Indicators III, 1948-1982 (ICPSR file 7761). 
United Nations (1993). World Population Prospects : The 1992 Revision. New York.

United Nations (1995). World Population Prospects : The 1994 Revision. New York.

World Bank (1993). World Tables of Economic and Social Indicators, 1950-1992 (ICPSR file 6159). Washington, DC: World Bank, International Economics Department (producer), 1993. Ann Arbor, MI : Interuniversity Consortium for Political and Social Research (distributor), 1997. 
Table 1

Testing Bequest Motives and Tax-Smoothing Approaches

Fixed (Country \& Time) Effects Panel Regressions

Dependent Variable: Central Government Budget Surplus Share

\begin{tabular}{|c|c|c|c|c|}
\hline \multirow[b]{2}{*}{ Years : $1975-1992$} & Developed & Developing & Developed & Developing \\
\hline & Reg 1a & Reg 1b & $\operatorname{Reg} 2 a$ & Reg $2 b$ \\
\hline \multicolumn{5}{|l|}{ Control Variables } \\
\hline 1. Dependent Variable Lag 1 & $\begin{array}{l}0.4008^{* * *} \\
(0.134)\end{array}$ & $\begin{array}{l}0.7074^{* * *} \\
(0.082)\end{array}$ & $\begin{array}{c}0.4018^{* * *} \\
(0.135)\end{array}$ & $\begin{array}{l}0.7073^{\star * *} \\
(0.082)\end{array}$ \\
\hline 2. Index of Political Rights & $\begin{array}{c}0.0233^{* *} \\
(0.009)\end{array}$ & $\begin{array}{r}-0.0009 \\
(0.002)\end{array}$ & $\begin{array}{c}0.0232^{* *} \\
(0.009)\end{array}$ & $\begin{array}{r}-0.0006 \\
(0.002)\end{array}$ \\
\hline 3. Agricultural Share (-) & $\begin{array}{l}-0.1046 \\
(0.28)\end{array}$ & $\begin{array}{r}-0.0855 \\
(0.074)\end{array}$ & $\begin{array}{r}-0.1072 \\
(0.284)\end{array}$ & $\begin{array}{l}-0.0876 \\
(0.073)\end{array}$ \\
\hline 4. Manufacturing Share $(+)$ & $\begin{array}{l}0.2475 \\
(0.215)\end{array}$ & $\begin{array}{l}-0.2522 \\
(0.216)\end{array}$ & $\begin{array}{l}0.2544 \\
(0.216)\end{array}$ & $\begin{array}{l}-0.2447 \\
(0.217)\end{array}$ \\
\hline 5. Trade Share $(+)$ & $\begin{array}{r}-0.0033 \\
(0.053)\end{array}$ & $\begin{array}{l}0.0506^{* *} \\
(0.024)\end{array}$ & $\begin{array}{l}-0.004 \\
(0.053)\end{array}$ & $\begin{array}{c}0.0508^{* *} \\
(0.024)\end{array}$ \\
\hline 6. Urban Population Share $(+)$ & $\begin{array}{l}-0.0148^{* * *} \\
(0.004)\end{array}$ & $\begin{array}{c}-0.0039^{* * *} \\
(0.001)\end{array}$ & $\begin{array}{c}-0.0148^{* * *} \\
(0.004)\end{array}$ & $\begin{array}{c}-0.0041^{* * *} \\
(0.001)\end{array}$ \\
\hline 7. Log of per capita Real GDP & $\begin{array}{l}0.2139^{* * *} \\
(0.048)\end{array}$ & $\begin{array}{l}0.0509^{* * *} \\
(0.018)\end{array}$ & $\begin{array}{c}0.2126^{* * *} \\
(0.048)\end{array}$ & $\begin{array}{c}0.0553^{* * *} \\
(0.018)\end{array}$ \\
\hline 8. Government Crises (-) & $\begin{array}{r}-0.0002 \\
(0.001)\end{array}$ & $\begin{array}{r}-0.0015 \\
(0.002)\end{array}$ & $\begin{array}{r}-0.0001 \\
(0.001)\end{array}$ & $\begin{array}{r}-0.0016 \\
(0.002)\end{array}$ \\
\hline 9. Cost of Debt Servicing (-) & $\begin{array}{l}0.0225 \\
(0.065)\end{array}$ & $\begin{array}{l}0.0126 \\
(0.028)\end{array}$ & $\begin{array}{l}0.0228 \\
(0.065)\end{array}$ & $\begin{array}{c}0.012 \\
(0.028)\end{array}$ \\
\hline 10. Seigniorage (-) & $\begin{array}{l}-0.0942 \\
(0.104) \\
\end{array}$ & $\begin{array}{l}-0.125 \\
(0.079)\end{array}$ & $\begin{array}{l}-0.0906 \\
(0.102)\end{array}$ & $\begin{array}{c}-0.1297 \\
(0.08)\end{array}$ \\
\hline \multicolumn{5}{|l|}{ Tax-Smoothing Variables } \\
\hline $\begin{array}{l}\text { 11. Unanticipated changes } \\
\text { in real per capita govt exp (-) } \\
\text { (4 year, simple average) }\end{array}$ & $\begin{array}{r}-0.0453 \\
(0.027)\end{array}$ & $\begin{array}{c}-0.0913^{* * *} \\
(0.02)\end{array}$ & $\begin{array}{c}-0.0453^{*} \\
(0.027)\end{array}$ & $\begin{array}{l}-0.0913^{* * *} \\
(0.02)\end{array}$ \\
\hline $\begin{array}{l}\text { 12. Unanticipated changes } \\
\text { in per capita real GDP }(+) \\
\text { (4 year, simple average) }\end{array}$ & $\begin{array}{l}-0.0752 \\
(0.052)\end{array}$ & $\begin{array}{l}0.1071^{* * *} \\
(0.026)\end{array}$ & $\begin{array}{r}-0.0751 \\
(0.053)\end{array}$ & $\begin{array}{l}0.1065^{* * *} \\
(0.026)\end{array}$ \\
\hline \multicolumn{5}{|l|}{ Bequest-Motives Variables } \\
\hline $\begin{array}{l}\text { 13. Expected per capita real } \\
\text { GDP Growth Rate }(-) \\
\text { (25 year construction) }\end{array}$ & $\begin{array}{l}-0.6268^{* *} \\
(0.296)\end{array}$ & $\begin{array}{l}-0.2173 \\
(0.482)\end{array}$ & $\begin{array}{l}-0.6144^{* *} \\
(0.297)\end{array}$ & $\begin{array}{l}-0.2628 \\
(0.491)\end{array}$ \\
\hline $\begin{array}{l}\text { 14. Gini Coefficient (-) } \\
\text { (adjusted, smoothed) }\end{array}$ & $\begin{array}{c}0.0009 \\
(0.0007)\end{array}$ & $\begin{array}{l}-0.0013 \\
(0.0034)\end{array}$ & $\begin{array}{c}0.0009 \\
(0.0007)\end{array}$ & $\begin{array}{l}-0.0018 \\
(0.0035)\end{array}$ \\
\hline 15. Life Expectancy at age 65 (-) & $\begin{array}{l}-0.0115 \\
(0.008)\end{array}$ & $\begin{array}{c}-0.0205^{*} \\
(0.011)\end{array}$ & $\begin{array}{r}-0.0115 \\
(0.008)\end{array}$ & $\begin{array}{c}-0.0204^{*} \\
(0.011)\end{array}$ \\
\hline 16. Youth Population Share (-) & $\begin{array}{l}0.1195 \\
(0.19)\end{array}$ & $\begin{array}{l}-0.2076 \\
(0.158)\end{array}$ & & \\
\hline 17. Working-Age Population Share $(+)$ & & & $\begin{array}{l}-0.0854 \\
(0.202)\end{array}$ & $\begin{array}{l}0.1816 \\
(0.172)\end{array}$ \\
\hline 18. Elderly Population Share (-) & $\begin{array}{l}0.4932^{*} \\
(0.293)\end{array}$ & $\begin{array}{r}-0.9739 \\
(0.983)\end{array}$ & $\begin{array}{l}0.3857 \\
(0.276)\end{array}$ & $\begin{array}{r}-1.0107 \\
(0.981)\end{array}$ \\
\hline 19. constant & $\begin{array}{l}-1.1222^{* * *} \\
(0.413)\end{array}$ & $\begin{array}{l}0.3264 \\
(0.198)\end{array}$ & $\begin{array}{r}-1.01^{* * *} \\
(0.373)\end{array}$ & $\begin{array}{l}0.1662 \\
(0.185)\end{array}$ \\
\hline R-squared & 0.8724 & 0.8351 & 0.8723 & 0.8414 \\
\hline Adjusted R-squared & 0.8408 & 0.7909 & 0.8407 & 0.7989 \\
\hline F-Statistic & 47.92 & 36.07 & 47.11 & 55.09 \\
\hline F-Stat df 1 & 52 & 66 & 52 & 66 \\
\hline F-Stat df 2 & 210 & 250 & 210 & 250 \\
\hline Number of Countries & 20 & 35 & 20 & 35 \\
\hline Number of Observations & 263 & 318 & 263 & 318 \\
\hline $\begin{array}{l}\text { andard Errors are in parentheses. } \\
\text { **, } \\
\text { bbust standard errors obtained using White's }\end{array}$ & onflaence & $\begin{array}{l}\text { spectively } \\
\text { ty. }\end{array}$ & & \\
\hline
\end{tabular}


Table 2

Testing Bequest Motives and Tax-Smoothing Approaches

Fixed (Country \& Time) Effects Panel Regressions

Dependent Variable: Central Government Budget Surplus Share

\begin{tabular}{|c|c|c|c|c|}
\hline \multirow[b]{2}{*}{ Years : $1975-1992$} & Developed & Developing & Developed & Developing \\
\hline & Reg 3a & Reg 3b & $\operatorname{Reg} 4 a$ & Reg 4b \\
\hline \multicolumn{5}{|l|}{ Control Variables } \\
\hline 1. Dependent Variable Lag 1 & $\begin{array}{c}0.4326^{* * *} \\
(0.127)\end{array}$ & $\begin{array}{l}0.718^{* * *} \\
(0.085)\end{array}$ & $\begin{array}{c}0.4332^{* * *} \\
(0.128)\end{array}$ & $\begin{array}{c}0.7164^{* * *} \\
(0.085)\end{array}$ \\
\hline 2. Index of Political Rights & $\begin{array}{c}0.0242^{* * *} \\
(0.009)\end{array}$ & $\begin{array}{c}-0.0009 \\
(0.002)\end{array}$ & $\begin{array}{l}0.024^{* * *} \\
(0.009)\end{array}$ & $\begin{array}{c}-0.0006 \\
(0.002)\end{array}$ \\
\hline 3. Agricultural Share (-) & $\begin{array}{l}-0.0527 \\
(0.273)\end{array}$ & $\begin{array}{r}-0.0939 \\
(0.075)\end{array}$ & $\begin{array}{l}-0.0531 \\
(0.277)\end{array}$ & $\begin{array}{r}-0.0957 \\
(0.074)\end{array}$ \\
\hline 4. Manufacturing Share $(+)$ & $\begin{array}{c}0.2484 \\
(0.22)\end{array}$ & $\begin{array}{c}-0.2389 \\
(0.215)\end{array}$ & $\begin{array}{l}0.2559 \\
(0.221)\end{array}$ & $\begin{array}{c}-0.2336 \\
(0.216)\end{array}$ \\
\hline 5. Trade Share $(+)$ & $\begin{array}{c}-0.0035 \\
(0.053)\end{array}$ & $\begin{array}{l}0.0473^{*} \\
(0.024)\end{array}$ & $\begin{array}{r}-0.0047 \\
(0.053)\end{array}$ & $\begin{array}{l}0.0469 * \\
(0.024)\end{array}$ \\
\hline 6. Urban Population Share $(+)$ & $\begin{array}{c}-0.0129 * * * \\
(0.003)\end{array}$ & $\begin{array}{c}-0.0039 * * * \\
(0.001)\end{array}$ & $\begin{array}{c}-0.013^{* * *} \\
(0.003)\end{array}$ & $\begin{array}{c}-0.0043^{* * *} \\
(0.001)\end{array}$ \\
\hline 7. Log of per capita Real GDP & $\begin{array}{l}0.191^{* * *} \\
(0.046)\end{array}$ & $\begin{array}{c}0.0462^{* * *} \\
(0.017)\end{array}$ & $\begin{array}{c}0.1896^{* * *} \\
(0.046)\end{array}$ & $\begin{array}{c}0.0517^{* * *} \\
(0.017)\end{array}$ \\
\hline 8. Government Crises (-) & $\begin{array}{r}-0.0002 \\
(0.001)\end{array}$ & $\begin{array}{c}-0.0029 \\
(0.002)\end{array}$ & $\begin{array}{r}-0.0001 \\
(0.001)\end{array}$ & $\begin{array}{r}-0.0031 \\
(0.002)\end{array}$ \\
\hline 9. Cost of Debt Servicing (-) & $\begin{array}{l}0.0347 \\
(0.065)\end{array}$ & $\begin{array}{c}0.0135 \\
(0.03)\end{array}$ & $\begin{array}{c}0.035 \\
(0.065)\end{array}$ & $\begin{array}{l}0.0133 \\
(0.029)\end{array}$ \\
\hline 10. Seigniorage (-) & $\begin{array}{c}-0.0897 \\
(0.1) \\
\end{array}$ & $\begin{array}{r}-0.1209 \\
(0.078) \\
\end{array}$ & $\begin{array}{r}-0.0856 \\
(0.099) \\
\end{array}$ & $\begin{array}{r}-0.1236 \\
(0.079) \\
\end{array}$ \\
\hline \multicolumn{5}{|l|}{ Tax-Smoothing Variables } \\
\hline $\begin{array}{l}\text { 11. Unanticipated changes } \\
\text { in real per capita govt exp (-) } \\
\text { (4 year, simple average) }\end{array}$ & $\begin{array}{c}-0.0489^{*} \\
(0.027)\end{array}$ & $\begin{array}{c}-0.0913^{* * *} \\
(0.021)\end{array}$ & $\begin{array}{l}-0.049^{*} \\
(0.027)\end{array}$ & $\begin{array}{c}-0.0912^{* * *} \\
(0.021)\end{array}$ \\
\hline $\begin{array}{l}\text { 12. Unanticipated changes } \\
\text { in per capita real GDP }(+) \\
\text { (4 year, simple average) } \\
\end{array}$ & $\begin{array}{r}-0.0687 \\
(0.051)\end{array}$ & $\begin{array}{c}0.1097^{* * *} \\
(0.026)\end{array}$ & $\begin{array}{c}-0.0686 \\
(0.051)\end{array}$ & $\begin{array}{c}0.1089^{* * *} \\
(0.026)\end{array}$ \\
\hline \multicolumn{5}{|l|}{ Bequest-Motives Variables } \\
\hline $\begin{array}{l}\text { 13. Expected per capita real } \\
\text { GDP Growth Rate (-) } \\
\text { (25 year construction) }\end{array}$ & $\begin{array}{c}-0.6021^{* *} \\
(0.297)\end{array}$ & $\begin{array}{l}0.0336 \\
(0.498)\end{array}$ & $\begin{array}{l}-0.586^{*} \\
(0.299)\end{array}$ & $\begin{array}{r}-0.0121 \\
(0.501)\end{array}$ \\
\hline $\begin{array}{l}\text { 14. Gini Coefficient (-) } \\
\text { (adjusted, smoothed) }\end{array}$ & $\begin{array}{c}0.0010 \\
(0.0007)\end{array}$ & $\begin{array}{l}-0.0015 \\
(0.0034)\end{array}$ & $\begin{array}{c}0.0010 \\
(0.0007)\end{array}$ & $\begin{array}{l}-0.0021 \\
(0.0035)\end{array}$ \\
\hline 15. Life Expectancy at age 65 (-) & & & & \\
\hline 16. Youth Population Share (-) & $\begin{array}{l}0.0922 \\
(0.193)\end{array}$ & $\begin{array}{c}-0.2844^{*} \\
(0.161)\end{array}$ & & \\
\hline 17. Working-Age Population Share $(+)$ & & & $\begin{array}{r}-0.0488 \\
(0.209)\end{array}$ & $\begin{array}{l}0.2943^{*} \\
(0.171)\end{array}$ \\
\hline 18. Elderly Population Share (-) & $\begin{array}{l}0.5076^{*} \\
(0.294)\end{array}$ & $\begin{array}{r}-1.1418 \\
(0.982)\end{array}$ & $\begin{array}{l}0.4291 \\
(0.288)\end{array}$ & $\begin{array}{r}-1.2178 \\
(0.976)\end{array}$ \\
\hline 19. constant & $\begin{array}{l}-1.1902^{* * *} \\
(0.401)\end{array}$ & $\begin{array}{l}0.0181 \\
(0.148)\end{array}$ & $\begin{array}{c}-1.1109^{* * *} \\
(0.36)\end{array}$ & $\begin{array}{l}-0.2338^{*} \\
(0.136)\end{array}$ \\
\hline R-squared & 0.8691 & 0.8350 & 0.8690 & 0.8464 \\
\hline Adjusted R-squared & 0.8375 & 0.7917 & 0.8374 & 0.8060 \\
\hline F-Statistic & 45.96 & 44.94 & 45.21 & 70.35 \\
\hline F-Stat df 1 & 51 & 65 & 51 & 65 \\
\hline F-Stat df 2 & 211 & 251 & 211 & 251 \\
\hline Number of Countries & 20 & 35 & 20 & 35 \\
\hline Number of Observations & 263 & 318 & 263 & 318 \\
\hline $\begin{array}{l}\text { Standard Errors are in parentheses. } \\
{ }^{*},{ }^{* *},{ }^{* *} \text { denotes significance at the } 90,95 \text { and } \\
\text { Robust standard errors obtained using White's }\end{array}$ & confidence & $\begin{array}{l}\text { spectively } \\
\text { ity. }\end{array}$ & & \\
\hline
\end{tabular}


Table 3

Testing Bequest Motives and Tax-Smoothing Approaches

Fixed (Country \& Time) Effects Panel Regressions

Dependent Variable: Central Government Budget Surplus Share

\begin{tabular}{|c|c|c|c|c|}
\hline \multirow[b]{2}{*}{ Years : $1975-1992$} & Developed & Developing & Developed & Developing \\
\hline & Reg 5a & Reg 5b & Reg 6a & Reg $6 b$ \\
\hline \multicolumn{5}{|l|}{ Control Variables } \\
\hline 1. Dependent Variable Lag 1 & $\begin{array}{c}0.4124^{* * *} \\
(0.134)\end{array}$ & $\begin{array}{c}0.7121^{* * *} \\
(0.083)\end{array}$ & $\begin{array}{c}0.4005^{* * *} \\
(0.135)\end{array}$ & $\begin{array}{c}0.7086^{* * *} \\
(0.083)\end{array}$ \\
\hline 2. Index of Political Rights & $\begin{array}{c}0.0222^{* *} \\
(0.009)\end{array}$ & $\begin{array}{r}-0.0002 \\
(0.002)\end{array}$ & $\begin{array}{l}0.0232^{* *} \\
(0.009)\end{array}$ & $\begin{array}{l}-0.0007 \\
(0.002)\end{array}$ \\
\hline 3. Agricultural Share (-) & $\begin{array}{r}-0.1222 \\
(0.281)\end{array}$ & $\begin{array}{c}-0.0906 \\
(0.073)\end{array}$ & $\begin{array}{c}-0.1072 \\
(0.28)\end{array}$ & $\begin{array}{c}-0.0883 \\
(0.073)\end{array}$ \\
\hline 4. Manufacturing Share $(+)$ & $\begin{array}{c}0.2595 \\
(0.22)\end{array}$ & $\begin{array}{c}-0.2317 \\
(0.216)\end{array}$ & $\begin{array}{l}0.2525 \\
(0.215)\end{array}$ & $\begin{array}{c}-0.2416 \\
(0.216)\end{array}$ \\
\hline 5. Trade Share $(+)$ & $\begin{array}{c}-0.0054 \\
(0.053)\end{array}$ & $\begin{array}{l}0.049^{* *} \\
(0.024)\end{array}$ & $\begin{array}{c}-0.0038 \\
(0.053)\end{array}$ & $\begin{array}{c}0.0502^{* *} \\
(0.024)\end{array}$ \\
\hline 6. Urban Population Share $(+)$ & $\begin{array}{c}-0.0149^{* * *} \\
(0.004)\end{array}$ & $\begin{array}{c}-0.0035^{* * *} \\
(0.001)\end{array}$ & $\begin{array}{c}-0.0149^{* * *} \\
(0.004)\end{array}$ & $\begin{array}{c}-0.0039^{* * *} \\
(0.001)\end{array}$ \\
\hline 7. Log of per capita Real GDP & $\begin{array}{c}0.221^{\text {*** }} \\
(0.048)\end{array}$ & $\begin{array}{c}0.0532^{* * *} \\
(0.018)\end{array}$ & $\begin{array}{c}0.2126^{\star * *} \\
(0.048)\end{array}$ & $\begin{array}{c}0.0549^{* * *} \\
(0.018)\end{array}$ \\
\hline 8. Government Crises (-) & $\begin{array}{l}-0.0007 \\
(0.001)\end{array}$ & $\begin{array}{c}-0.0009 \\
(0.002)\end{array}$ & $\begin{array}{c}-0.00003 \\
(0.001)\end{array}$ & $\begin{array}{c}-0.0014 \\
(0.002)\end{array}$ \\
\hline 9. Cost of Debt Servicing (-) & $\begin{array}{l}0.0142 \\
(0.065)\end{array}$ & $\begin{array}{l}0.0125 \\
(0.028)\end{array}$ & $\begin{array}{l}0.0241 \\
(0.065)\end{array}$ & $\begin{array}{c}0.012 \\
(0.028)\end{array}$ \\
\hline 10. Seigniorage (-) & $\begin{array}{r}-0.1102 \\
(0.104) \\
\end{array}$ & $\begin{array}{c}-0.1248 \\
(0.079) \\
\end{array}$ & $\begin{array}{r}-0.0877 \\
(0.103) \\
\end{array}$ & $\begin{array}{r}-0.1269 \\
(0.079) \\
\end{array}$ \\
\hline \multicolumn{5}{|l|}{ Tax-Smoothing Variables } \\
\hline $\begin{array}{l}\text { 11. Unanticipated changes } \\
\text { in real per capita govt exp (-) } \\
\text { (4 year, simple average) }\end{array}$ & $\begin{array}{r}-0.0461 \\
(0.028)\end{array}$ & $\begin{array}{c}-0.0913^{\star * *} \\
(0.021)\end{array}$ & $\begin{array}{c}-0.0452^{*} \\
(0.027)\end{array}$ & $\begin{array}{c}-0.0914^{* * *} \\
(0.02)\end{array}$ \\
\hline $\begin{array}{l}\text { 12. Unanticipated changes } \\
\text { in per capita real GDP }(+) \\
\text { (4 year, simple average) }\end{array}$ & $\begin{array}{l}-0.077 \\
(0.053)\end{array}$ & $\begin{array}{c}0.1073^{* * *} \\
(0.026)\end{array}$ & $\begin{array}{c}-0.0749 \\
(0.052)\end{array}$ & $\begin{array}{l}0.107^{* * *} \\
(0.026)\end{array}$ \\
\hline \multicolumn{5}{|l|}{ Bequest-Motives Variables } \\
\hline $\begin{array}{l}\text { 13. Expected per capita real } \\
\text { GDP Growth Rate }(-) \\
\text { (25 year construction) }\end{array}$ & $\begin{array}{c}-0.7784^{* *} \\
(0.319)\end{array}$ & $\begin{array}{c}-0.2956 \\
(0.451)\end{array}$ & $\begin{array}{c}-0.6116^{* *} \\
(0.297)\end{array}$ & $\begin{array}{c}-0.2293 \\
(0.478)\end{array}$ \\
\hline $\begin{array}{l}\text { 14. Gini Coefficient (-) } \\
\text { (adjusted, smoothed) }\end{array}$ & $\begin{array}{l}-0.0008 \\
(0.0007)\end{array}$ & $\begin{array}{l}-0.0008 \\
(0.0032)\end{array}$ & $\begin{array}{c}0.0009 \\
(0.0007)\end{array}$ & $\begin{array}{l}-0.0013 \\
(0.0033)\end{array}$ \\
\hline 15. Life Expectancy at age 65 (-) & $\begin{array}{r}-0.0122 \\
(0.009)\end{array}$ & $\begin{array}{c}-0.0218^{* *} \\
(0.011)\end{array}$ & $\begin{array}{l}-0.0115 \\
(0.008)\end{array}$ & $\begin{array}{c}-0.0206^{*} \\
(0.011)\end{array}$ \\
\hline 16. Total Dependency Ratio (-) & $\begin{array}{l}0.0627 \\
(0.082)\end{array}$ & $\begin{array}{l}-0.0457 \\
(0.057)\end{array}$ & & \\
\hline 17. Youth Dependency Ratio (-) & & & $\begin{array}{l}-0.0012 \\
(0.092)\end{array}$ & $\begin{array}{l}-0.0348 \\
(0.065)\end{array}$ \\
\hline 18. Elderly Dependency Ratio (-) & & & $\begin{array}{l}0.266^{*} \\
(0.153)\end{array}$ & $\begin{array}{l}-0.4966 \\
(0.578)\end{array}$ \\
\hline 19. constant & $\begin{array}{c}-1.1082^{* * *} \\
(0.406)\end{array}$ & $\begin{array}{l}0.1958 \\
(0.183)\end{array}$ & $\begin{array}{c}-1.0647^{* \star *} \\
(0.41)\end{array}$ & $\begin{array}{l}0.2461 \\
(0.183)\end{array}$ \\
\hline R-squared & 0.8703 & 0.8305 & 0.8724 & 0.8344 \\
\hline Adjusted R-squared & 0.8389 & 0.7859 & 0.8408 & 0.7900 \\
\hline F-Statistic & 50.99 & 35.68 & 46.94 & 36.16 \\
\hline F-Stat df 1 & 51 & 65 & 52 & 66 \\
\hline F-Stat df 2 & 211 & 251 & 210 & 250 \\
\hline Number of Countries & 20 & 35 & 20 & 35 \\
\hline Number of Observations & 263 & 318 & 263 & 318 \\
\hline \multicolumn{5}{|c|}{$\begin{array}{l}\text { Standard Errors are in parentheses. } \\
{ }^{*},{ }^{* *},{ }^{* *} \text { denotes significance at the } 90,95 \text { and } 99 \text { percent confidence level respectively } \\
\text { Robust standard errors obtained using White's correction for heteroscedasticity. }\end{array}$} \\
\hline
\end{tabular}




\section{APPENDIX}

\section{A.1 Description of Data}

The intended coverage of the regression is from 1950 to 1995 and covers 87 countries. The complete list of countries is presented in the chapter appendix. Table A presents the sources and definitions of all raw data used.

\section{A.2 How the Variables are Constructed}

\section{Dependent Variable}

The fiscal surplus of the central government as a share of GDP in year $t$ is defined as the ratio of central government budget surplus or deficit (-) in year $t$ to nominal GDP in year $t$.

\section{Independent Variables}

Control Variables

1. Index of political rights in year t. The index runs from "1" to "7", with "1" denoting the highest level political rights or most political freedom.

2. Agricultural share in year $t=$ ratio of the value added in the agricultural sector in year $t$ to nominal GDP in year $t$.

3. Manufacturing share in year $t=$ ratio of the value added in the manufacturing sector in year $t$ to nominal GDP in year $t$.

4. Trade share in year $t=$ ratio of the sum of imports and exports in year $t$ to nominal GDP in year $t$.

5. Urban population share in year $t=$ ratio of urban population in year $t$ to total population in year $t$. 
6. Political instability in year $t=$ number of government crises in year $t$.

7. Development variable: log of per capita real GDP in year $t$.

The measurement of per capita real GDP needs to be comparable across countries. For this reason, data for this variable was obtained from the HestonSummers data set "Penn World Tables Mark 5.6" (Heston and Summers, 1991) ${ }^{23}$. The measure of real GDP used in this paper will be real GDP per capita measured in constant dollars that has been adjusted for changes in the terms of trade, using 1985 international prices for domestic absorption (consumption, investment and government purchases) and current international prices for exports and imports. This measured was devised to take account of changes in the value of the country's output arising from changes in its terms of trade as well as changes in its production. The domestic absorption part is calculated using 1985 international prices. However, the net foreign balance is valued in current prices instead of 1985 prices. This is to allow for the part of the country's increased well being that results form lower prices paid for imports or higher prices received for exports.

8. Seigniorage share $=$ the ratio of the difference in the stock of reserve money between year $t$ and year $t-1$ to that of nominal GDP in year $t$.

9. Cost of debt servicing = annual change of the difference between the real interest rate and the real GDP growth rate, multiplied by lagged debt-GDP ratio, where the real interest rate is defined as

Real Interest Rate $=\left[(1+\right.$ Deposit Interest Rate in year $\left.\mathrm{t}) * \frac{\text { GDP Deflator in year } \mathrm{t}-1}{\text { GDP Deflator in year } \mathrm{t}}\right]-1$

\footnotetext{
${ }^{23}$ The Penn World Tables display a set of national accounts economic time series covering a large number of countries. Its unique feature is that its expenditure entries are denominated in a common set of prices in a common currency so that real international quantity comparisons can be made both countries and over time; see Summers and Heston (1991).
} 


\section{Tax-Smoothing Variables}

Recall that the tax smoothing approach postulates that unanticipated increases in government expenditure will tend increase the budget deficit (and vice versa), while unanticipated increases in output will tend decrease the budget deficit (and vice versa). To obtain a proxy for unanticipated changes in per capita real government expenditures, we shall use the percentage deviation of the current level from the expected level of per capita government expenditure or:

$$
\frac{G_{t}-\bar{G}_{t}}{\bar{G}_{t}}
$$

where

$G_{t} \quad$ is the level of real per capita government expenditure in year $t$

$\bar{G}_{t} \quad$ is the expected level of per capita real government expenditure in year $t$ constructed by projecting the level of per capita real government expenditure in year $t-1$ by using an estimated annual growth rate of per capita real government expenditure. The estimated annual growth rate is the simple average of the previous three annual growth rates of per capita real government expenditure.

Similarly, to account for unanticipated changes in per capita output of the economy, we shall use the percentage deviation of the current level of real per capita GDP from the expected level of real per capita GDP or:

$$
\frac{Y_{t}-\bar{Y}_{t}}{\bar{Y}_{t}}
$$

where

$Y_{t} \quad$ is the level of real per capita GDP in year $t$

$\bar{Y}_{t} \quad$ is the expected level of real per capita GDP in year $t$ constructed by projecting the level of per capita real GDP in year $t-1$ by using an estimated annual growth rate of per capita output. The estimated annual growth rate is the OLS slope coefficient is the simple average of the previous three annual growth rates of the log of per capita real GDP.

Some will undoubtedly find the choice of previous 4 years for estimating the annual growth rate of per capita real government expenditure and output to be extremely arbitrary $^{24}$. The sensitivity analyses section in the appendix presents regression results

\footnotetext{
${ }^{24}$ Note that using the simple average of the previous 3 annual growth rates is equivalent to using 4 years of data.
} 
where alternative numbers of years, as well as a different method, are used to estimate annual growth rates for both tax-smoothing variables ${ }^{25}$.

\section{Negative Bequest Motive Regressors}

1. Expected per capita real GDP growth rate of the economy

Recall that Cukierman and Meltzer postulated that as the expected real GDP growth rate increases, people would tend to expect future generations to have a higher standard of living relative to the current generation. Thus, this tends to increase the share of bequest-constrained individuals in the population. In this light, expected per capita real GDP growth rate, rather than the expected growth rate in aggregate GDP, is more intuitively appealing as a proxy for the expected welfare of future generations. This was constructed as the slope coefficient of a "rolling regression" of the preceding 25 years' log of the real per capita GDP on a time trend. More specifically, the expected per capita real GDP growth rate of the economy in year $t$ would be the slope coefficient obtained when the log of real per capita GDP for the years $t-1$ through $t-25$ is linearly regressed on a time trend ${ }^{26}$.

\section{The distribution of income or total wealth}

A suitable proxy for the spread of the income distribution is the Gini coefficient. Data for Gini coefficients are from Deininger and Squire (1996) and only observations that are in the "accepted" category are used. Observations in this category are considered by Deininger and Squire to be relatively more consistent, more accurately measured, and reliable. However, this data set includes Gini coefficients of different measures. Two different measures are income and expenditure based Gini coefficients. Since individuals are better able to smooth expenditure as opposed to income, Gini coefficients based on expenditure measures are, ceteris paribus, smaller than those based on income. Deininger and Squire note that the mean difference between the two

\footnotetext{
${ }^{25}$ Roubini and Sachs (1989a) model unanticipated changes in output for a country as the deviation of actual output from its average value over the previous three years in that country. However, note that since output usually has an upward trend, this method will tend have an upward bias in unanticipated increases in output, since the measure of average value of output will consistently under-predict the true "expected value".

${ }^{26}$ The choice of using the past 25 years is somewhat arbitrary. Alternatives, such as using data on the log of per capita GDP of the past 15, 20 and 30 years, have been presented in the sensitivity analyses in Chen (2001).
} 
is about 6.6 out of 100, and recommend adding the difference of 6.6 between expenditure-based and income based coefficients to the expenditure based Gini coefficients in the sample ${ }^{27}$ to avoid the exclusion of a substantial number of countries. We follow their suggestion.

Another problem with the data set was that the available observations were irregularly spaced and relatively scarce. We note that the true gross income distributions tend to change very slowly and that there will be unavoidable inconsistencies in the measurement of the Gini coefficient, (both across countries and across time). In order to minimize the effect of extreme observations and to increase the number of annual observations, the available data were smoothed using locally weighted scatterplot smoothing (lowess) and then linear interpolation was performed using the new smoothed observations ${ }^{28}$. The "adjusted and smoothed" Gini coefficients were then used in the regressions ${ }^{29}$.

\section{Expected longevity}

The bequest motives model postulates that the longer the period of time an individual spends in retirement, the more likely he or she is likely to be bequestconstrained. The Proposition thus indicates that an increase in expected longevity will lead to a larger budget deficit, under majority rule.

\footnotetext{
${ }^{27}$ Such an adjustment, they argue, would be supported by the fact that the difference between income and expenditure based Gini coefficient does not does not to seem to follow any distinguishing pattern, except that it narrows over time. Thus it is not significantly correlated at the $5 \%$ levels with levels of income, continent dummies or the average levels of the Gini in the country but correlated negatively (with a correlated of 0.47 ) with time.

${ }^{28}$ The smoothed values are obtained by running a regression of the original Gini coefficient data on time. Each smoothed value of the Gini coefficient is generated using the original Gini coefficient for that particular year and a small amount information of the actual Gini coefficients observed in the past and future years. In this method, the regression is weighted so that the central point, the Gini coefficient in year $t\left(\right.$ ginit $_{t}$, year $\left.{ }_{t}\right)$ gets the highest weight and points farther away (based on the distance $\left|g i n i_{s}-g i n i_{t}\right|$ receive less. The estimated regression is then used to predict the smoothed value $g i \hat{n} i_{t}$ based on gini $i_{t}$ only. The procedure is repeated to obtain the remaining smoothed values, which means a separated weighted regression is estimated for every point in the data. A bandwidth of 0.5 was used, which implies that centered subsets of 50 per cent of the observations are used for calculating smoothed values for each point. The greater the bandwidth, the greater the smoothing.
}

${ }^{29}$ The results of panel regressions in which the Gini coefficients are neither adjusted nor smoothed are presented in the appendix for comparison. 
In view of the above, a very appropriate variable for use as a proxy for the expected time an individual expects to spend in retirement is life expectancy at age $65^{30}$. However, across the 87 countries included in the sample, there is a less than satisfactory number of observations for life expectancy at age 65 . The problem of insufficient data is especially severe for the less developed countries, with some of them having as few as 3 observations out of the possible 45 years of data. On the other hand, data for life expectancy at birth is relatively more abundant with annual observations being available even for the less developed countries. Given the high correlation between life expectancy at age 65 and life expectancy at birth ${ }^{31}$, a simple way to get around problem of having insufficient number of observations for "life expectancy at age 65" would have been to use "life expectancy at birth" as a proxy. However, in order to get a more accurate representation of the expected time an individual spends in retirement, a less crude technique was used. This technique involves the use of the available data on life expectancy at birth and at age 65 to make out of sample predictions for years in which data on life expectancy at birth is available but life expectancy at age 65 is not. For details, please refer to the construction of Method 2 of estimating life expectancy at age 65 in Chen (2001).

\section{Age-Structure Variables}

Youth Population Share $=$ the ratio of the number of persons aged 14 and younger in year $t$ to the total number of persons in the population in year $t$.

Working-Age Population Share $=$ the ratio of the number of persons aged between 15 and 64 in year $t$ to the total number of persons in the population in year $t$.

Elderly Population Share $=$ the ratio of the number of persons aged 65 and over in year $t$ to the total number of persons in the population in year $t$.

\footnotetext{
${ }^{30}$ The expected additional number of years a person is expected to live, given that he or she has survived until age 65 .

${ }^{31}$ Based on the available 925 observations of the two life expectancies that coincide in terms of the country and year in our data set, we obtained a correlation coefficient of 0.8015 .
} 
Total Dependency Ratio = ratio of the sum of youth and elderly population in year $t$ relative to the total population in year $t$

Youth Dependency Ratio $=$ ratio of the youth population in year $t$ relative to the total population in year $t$

Elderly Dependency Ratio = ratio of the elderly population in year $t$ relative to the total population in year $t$ 
Table A: Description of Raw Data

\begin{tabular}{|c|c|c|c|}
\hline Variable & Definition & Frequency & Source \\
\hline Surplus or deficit (-) & Overall budget surplus of the central government & Annual & IFS, WB, WDI \\
\hline Debt & Total nominal debt issued by the central government & Annual & IFS, WDI \\
\hline Current revenue & $\begin{array}{l}\text { All government revenue from taxes and nonrepayable } \\
\text { receipts except grants }\end{array}$ & Annual & WDI \\
\hline Current expenditure & $\begin{array}{l}\text { All government expenditure excluding payments for } \\
\text { capital assets or goods and services to be used in the } \\
\text { production of capital assets }\end{array}$ & Annual & WDI \\
\hline Nominal GDP & Nominal Gross Domestic Product at market prices & Annual & IFS, WB, WDI \\
\hline Agriculture & Value added in the agricultural sector & Annual & WB, WDI \\
\hline Manufacturing & Value added in the manufacturing sector & Annual & WB, WDI \\
\hline Imports & Merchandise imports c.i.f. (US\$) & Annual & IFS, WB, WDI \\
\hline Exports & Total mechandise exports f.o.b. (US\$) & Annual & IFS, WB, WDI \\
\hline Exchange rate & Units of national currency per US dollar (Annual Average) & Annual & IFS, WB, WDI \\
\hline $\begin{array}{l}\text { Urban population } \\
\text { share }\end{array}$ & $\begin{array}{l}\text { The ratio of the urban population over the total population } \\
\text { multiplied by } 100\end{array}$ & Annual & WB, WDI \\
\hline $\begin{array}{l}\text { Number of } \\
\text { government crises }\end{array}$ & $\begin{array}{l}\text { The number of major government crisis, defined as any } \\
\text { rapidly developing situation that threatens to bring the } \\
\text { downfall of the present regime - excluding situations of } \\
\text { revolt aimed at such overthrow }\end{array}$ & $\begin{array}{l}\text { Decade } \\
\text { Average }\end{array}$ & Easterly (1997) \\
\hline Political rights & $\begin{array}{l}\text { Index from } 1 \text { to } 7 . A \text { " } 1 \text { " represents the highest level of } \\
\text { political rights while a "7" represents the lowest. }\end{array}$ & Annual & $\begin{array}{l}\text { Gastil (1973-1989), } \\
(1990)\end{array}$ \\
\hline $\begin{array}{l}\text { Per capita } \\
\text { real GDP }\end{array}$ & $\begin{array}{l}\text { Measured in constant dollars. Adjusted for changes } \\
\text { in the terms of trade, using } 1985 \text { international prices } \\
\text { for domestic absorption and current prices for } \\
\text { exports and imports. }\end{array}$ & Annual & $\begin{array}{l}\text { Heston and } \\
\text { Summers (1991) }\end{array}$ \\
\hline $\begin{array}{l}\text { Deposit } \\
\text { interest rates }\end{array}$ & $\begin{array}{l}\text { The rate paid by commercial or similar banks for } \\
\text { demand, time, or savings deposits. }\end{array}$ & Annual & IFS, WDI \\
\hline GDP deflator & GDP deflator (Base=1990) & Annual & WB, WDI \\
\hline Reserve money & Monetary base & Annual & IFS \\
\hline Income Distribution & Gini Coefficient & Annual & $\begin{array}{l}\text { Deininger and } \\
\text { Squire (1996) }\end{array}$ \\
\hline Youth Population & Number of persons aged 14 and below & Annual & WDI \\
\hline Working-age Population & Number of persons aged between 14 and 64 & Annual & WDI \\
\hline Elderly population & Number of persons aged 65 and above & Annual & WDI \\
\hline Total population & Total number of persons in the population & Annual & WDI, IFS \\
\hline $\begin{array}{l}\text { Elderly life } \\
\text { expectancy }\end{array}$ & Life expectancy at age 65 & Annual & $\begin{array}{l}\text { Demographic } \\
\text { Yearbook }\end{array}$ \\
\hline $\begin{array}{l}\text { Life expectancy } \\
\text { at birth }\end{array}$ & Life expectancy at age 0 & Annual & WB, WDI \\
\hline
\end{tabular}

WB $=$ World Bank (1983)

WDI = World Bank (1997), (1999)

IFS = International Monetary Fund (1998), (1999)

Demographic Yearbook (various issues) 